\title{
Factors Affecting Juvenile Delinquency in Punjab, Pakistan: A Case Study Conducted at Juvenile Prisons in Punjab Province
}

\author{
Umair Ahmed \\ Azka Murtaza \\ Department of Sociology, University of Sargodha, Sargodha, Pakistan
}

\section{Doi:10.5901/mjss.2016.v7n4p}

\begin{abstract}
The present study was to explore the factors affecting the juvenile delinquency in Punjab, Pakistan. The major objectives of the study were to find out the demographic and socioeconomic information of the respondents as well as to investigate the possible factors affecting juvenile delinquency. The study was qualitative in nature and the case study method was use for data collection from the prisons of Punjab, particularly located in the jails of three districts i.e. Lahore, Rawalpindi, \& Sargodha (District Jail Lahore, Central Jail Rawalpindi \& District Jail Sargodha). The researcher conducted 6 in depth interviews of the respondents by using the convenient sampling technique. The results show that there are many socioeconomic as well as psychological factors affecting juvenile delinquency in Punjab, Pakistan. Mostly respondents claimed that family environment i.e. restrictive behavior, negligence, improper supervision, and delinquent behavior of their parents leads to juvenile delinquency. Some respondents reported that the motivation by peers and friends for indulgence in deviancy and peer rejection also becomes the pull or push factors toward delinquency. Moreover, the poverty, illiteracy, poor educational performance at school and lack of moral education may turn the personalities toward law violators. The study also concluded that deteriorate neighborhood, direct exposure to violence and fighting movies on media also considered as the risk factors leads toward delinquency among juveniles.
\end{abstract}

Keywords: Juvenile Delinquency, Juvenile Prisons, Punjab, Pakistan.

\section{Introduction}

Juvenile delinquency is a global problem which is increasing day by day and impacting every segment of the society. Children of any society are considered as the up-coming future of their nation. If these assets of the society indulge in unlawful acts, then the progress of that society is at greater risk. Juvenile delinquency is basically the violation of law committed by the person who is not yet reached at the age of maturity. It is necessary to understand the term juvenile delinquency, delinquents and delinquent acts. The process has any unlawful act committed by the children or adolescent who did not reach at the age of 18 is called juvenile delinquency (Shoemaker, 2010).

The person who violates the laws of the state are considered as delinquent and their unlawful deviant act is called delinquent act. The term delinquent is only used when the rule breaker person acts upon the series of delinquent acts. The serious offenses, i.e. murder, rape, theft, robbery, arson and other illegal acts are at the greater concern of the Pakistani judicial system and certain measures have been formulated to overcome this problem. In Pakistan the condition of delinquency among juveniles emerged due to societal discrimination, social class differences, different pace of development among rural and urban setting, unemployment, illiteracy, improper role of family and schools etc. (Talpur et al, 2011).

There are many factors, i.e. socioeconomic and psychological which could become the cause of delinquency. The family is considered as a critical factor behind the children's indulgence in the delinquency. Many researches explained the relationship between family factors and criminality. The factors which are studied could be having criminal parents, too much strictness for the sake of discipline, negligence from parents, abuse from parents, lack of appropriate parental supervision, violence at the early age, parental early age marriages, parental behavior, use of drugs by parents, some sort of mental disorder by parents, birth order, family size, family structure, family education, and the economic status of the family. All the social researchers, expertise, and policymakers found that the family is an important factor behind deviancy (Loeber and Stouthammer, 1986).

Another research has linked to the above research, also concluded that the children having a single parent family are at greater risk to indulge in the deviant acts (McCord et al, 2001). 
Some other characteristic of family like having antisocial parents, substance abusing parent, parental psychopathology can put on the children toward deviancy. If the parents are antisocial, then there are greater chances of children indulgence toward deviancy. Moreover, children who faced substance abuse by their parents also are at greater risk to involve in unlawful acts in future. Similarly, parental psychological disorder is also a risk factor behind delinquency of the children (Lahey et al, 1988).

Negative peer influence is also a main aspect behind criminal behavior as the kids who have close involvement with deviant peers, can involve in unlawful acts. A bad, corrupt company can lead the adolescence having no criminal history to start delinquent acts or increase delinquent tendencies. Adolescence having a strong association with criminal peers is condemn and detained earlier than those who do not have such sort of involvement (Elliot et al. 1996; Coie et al, 1995).

There are many social processes which basically contribute to the exposure and learning of aggressive and violent behavior. Failure to social and academic achievements creates frustration in a variety of ways. The troubles normally arise due to extreme higher intensity of aggression, which go ahead to extra annoying encounters with parents, instructors, and friends. In the consequences of this, children spend most of their time with other nonconformists who have the greater pattern of aggressive behavior. These factors include low economic conditions, disorganized area, criminal peers, lack of proper and safe supervision, exposure to violent programs; criminal parents, and poor social support, etc. The person differences have also been recognized by their aggression, and hostility (Anderson, 2000).

Inequality is also a main factor behind criminality. Those people who have low income felt themselves deprived and wanted to attain the living standard of rich people whose income level is higher than lower. It is not possible to attain all the facilities of life with low family income legally, than people of low income families adopt illegal ways to attain a standard life. Education also plays an important role in crime reduction if it is correlated with higher wages. Basically, education can raise the standard of a person by legal way of earning wages and utilizing their skills (Gumus, 2004).

\subsection{Objectives}

The study was aimed to find out the following objectives.

- To find out the demographic and socio-economic information of the respondents.

- To explore the factors that promotes delinquency among juveniles.

- To suggest some policy measures to overcome the juvenile delinquency.

\subsection{Significance of study}

Juvenile delinquency is a social problem of every country including Pakistan. Generally conflicts arises due to extreme levels of discrimination among social classes which becomes a push or pull factor of indulgence in delinquency as children are highly influenced by the exposure to inappropriate environment. The present study is concerned to explore the factors affecting juvenile delinquency in the Punjab, Pakistan. This study is important as the concern for Pakistani children as well as adolescents, especially the age from seven to eighteen year old are highly affected by socioeconomic and psychological factors. This group is the up-coming future of our nation and they have to play a significant role in the progress of our country. Unfortunately, some of these children and adolescents become criminal in their future life due to inappropriate socializing environment and other psychological factors which negatively influenced in their cognitive and psychological development. The study is aimed to find out the factors leading children, who diverge from socio-cultural norms and values, and commit crime. The result of this study may confidently find out the causes and consequences of juvenile delinquency. The result may also be helpful for the juveniles to improve their behavior for their rehabilitation in the society and they can understand their significance in the development of the country which absolutely builds up the sense of commitment and responsibility in them. The study will provide better suggestions for the protection of juveniles from various abuses in the jails.

\section{Research Methodology}

The present research was qualitative in nature, and case study method was used for data collection. The universe of the present research was all the delinquents of juvenile prisons of Punjab province and for instance, the three districts of Punjab province in which include Sargodha, Rawalpindi \& Lahore had been selected randomly to gather the information. There were 746 juveniles in Punjab prisons, but researcher conducted only six case studies of juvenile delinquents by using convenient sampling to explore the factors of juvenile delinquency in Punjab. During the in-depth interviews; 
researcher used interview guide, audio recording, and diary as the instruments of data collection to collect relevant information regarding present research. The data was analyzed by using observation method, theoretical framework and existing research literature.

\section{Results and Discussion}

The present study was aimed to explore the factors affecting juvenile delinquency in Punjab, Pakistan. In this research, the stories of participants showed that the life experiences of juveniles at their early age, later happenings which push them toward deviancy or pull them from their conventional lives and the more significant their experiences after committing crimes and their lives in the jails highly influenced on their social development. It is found that there are following factors and consequences of the juvenile delinquency in the Punjab, Pakistan.

\subsection{Inadequate Family Environment}

Family is considered as the main socializing agent and it is the major contributor that pulls or pushes the juveniles into delinquency. If family is unable to play its role in a proper way then the chance of better outcome will be at greater risk. It is found that inadequate support by the family leads toward delinquency as children will try to find out some external support that will create such environment which paved the ways to involve in unlawful acts. If there is no friendly behaviour and proper sharing between parents and children, it will negatively influence on the mental development of the children and they will try to find out some external supporter. As stated;

"My parents never supported me and they forced me to earn money during my early age. I left school due to the unsupportive attitude of my family." Nasir Ali

Nasir Ali, 18 years old boy from 27 Chak, District Sargodha had been charged by robbery, firing and use of
illegal weapon under section $394 / 411$ and $13 / 20 / 65$. Briefly stated the story by offender showed that due to
improper supervision by parents, he spent most of his time behind television watching movies. One
occurrence day, he was watching an action movie. In the consequences of this, he took his pistol and went
to Ajnala Road, Bhalwal. He found there a college student in uniform. He pointed the pistol on him and
demanded to give him money and mobile phone. The boy resisted to give him anything. He wanted to afraid
the boy, so that's why he started firing. Mistakenly one bullet crossed from his ribs and he got sever injury.

Demuth and Brown, (2004) also concluded that due to the lack of parental control and lack of good relation between the adolescents and their parents become the cause of joining any criminal gang and become skilled lawbreaker.

Too much strictness and domestic violence from parents for maintaining discipline among children also contribute in generating delinquency. Some parents have criminal tendencies and they abuse their children physically or sexually which showed that the parents also have improper socialization and other psychological disorders. Moreover, the exposure to the violence at homes is also a strong predictor of delinquency among juveniles.

As one respondent stated as;

"I faced strictness at home from my elders; resultantly I became disinclined from my family". Syed Asad Ali Shah

Another respondent claimed as;

"My father and mother usually fought with each other, and father sometime slapped my mother". Muhammad Ahsan

Another respondent also claimed that;

"My father had beaten my mother due to their clashes; they usually remained in the state of conflicts". Shahid Maseeh

One respondent stated as:

"My father is a very aggressive person and he has beaten us and mother on our any sort of negligence". "My parents usually remained in the state of conflicts as father wanted to keep a proper check on the children, but mother drops a veil over our mistakes". Asghar Khan

Another resident stated as;

"My parents usually remained in the state of clashes due to family matters". Zeeshan Khan 
Bor et al, (1997) also reported that family violence is another forecaster for the risk factor of increasing juvenile delinquency. Usually the early age child has the exposure to violent activities at home, is more prone to accept and adopt such sort of behavior. If children face physical abuse at home, they will indulge themselves in violent activities later. Those families having large family size or lack of positive reinforcement, their children involve in deviancy due to improper family control.

It is also found that the children of single parent families or children having their step parents are at greater chances toward deviancy.

As stated; "My father's sudden death was a natural disaster for my family as we have to suffer a lot socially, emotionally, psychologically and financially". Syed Asad Ali Shah

Breivik et al, (2009) also reported that the single parental family is considered as a significant foreteller of deviancy. Many researchers concluded that the children having single parent families can involve in delinquent acts more than having two parent families.

A research on juvenile delinquency also draws a link that any sort of deviation found in the family is negatively affected on its member's especially it's adolescent. Family is a crucial determinant which is demonstrated for the juvenile delinquency. There are different aspects of family for determining the nature and the causes of juvenile delinquency i.e. age, gender, family structure, economic conditions of the family, family control, bonding with religion as a controlling agent, parental supervision, family strict behaviour, parental rejection and affection etc. (Canter, 1982; Datesman and Scarpitti, 1975).

The large family size also considered as risk factor leading toward improper socialization of their children due to lack of proper attention to all children.
"I have six brothers and three sisters and my number among siblings was six". Muhammad Ehsan
"I have three brothers and two sisters and my number among sibling was third". Shahid Maseeh
"I have three sisters and two brothers and my number among siblings was second". Syed Asad Ali Shah
"I have four sisters and two brothers and my number among siblings was third". Zeeshan khan
"I have two brothers and one sister, and my number among siblings was third". Asghar Khan

Jones et al, (1980) also concluded that the there is strong relationship between criminal tendency and concentration given by the parents at sibling number. It is also found that parents pay less attention to their children where there is large family size having more number of children. In the consequences of this, the children have more chances to commit crime. Research also concluded that in such families' male are at the more chances to indulge in delinquency.

\begin{abstract}
Shahid Maseh, 17 years old boy from Bashir Chaudry Chaok, Lahore was charged by murder, gang robbery, use of illegal weapon under section $302 / 34, \& 13 / 20 / 65$. The facts show that his paternal aunt's husband was a rich man. He and his elder brother made a plan to burgle him with the assistance of their professional gang. They informed the gang and decided the time and target place. On the occurrence day, they went to his uncle (aunt, husband) home at 4 o'clock. His uncle was alone at home as his parental aunt was in her parents' home. They robbed the home at gunpoint, but unfortunately, his uncle recognized the offender and start shouting for help. They killed him by two fires and knife cuts on his chest due to his resistance. After 20 days, during police investigation, police got their blooded dresses in the offender's house and caught them.
\end{abstract}

\title{
3.2 Negative Peer Influence
}

It is found that the peers also play a significant role in the socialization of the children. The negative influence of peers also tends toward the delinquency. They have strong association with their peers instead of their families which become the cause of their delinquent acts.

Zeshan Khan, 16 years old boy from Sabzi Mandi, Islamabad and he was charged for robbery under section 392. On the occurrence day, Zeshan with his three friends robbed a neighbor's home on day 3, o'clock. They steal the money (30,000 rupees), LED (television), gold of two hundred thousand rupees, refrigerator from the victim's home. After two days, the respondent with his one friend were apprehended by Islamabad police.

As respondents stated as;

"I usually lived with my friends or on the workplace. One of my friends was involved in unlawful acts, but he is very kind hearted and supported me always. Nasir Ali

"One of my friends was involved in unlawful acts." Syed Asad Ali Shah 
"Some of my friends were involved in unlawful acts due to their poor socioeconomic conditions". Zeeshan Khan

As Postman, (1982) also described that there are many social factors that lead the persons toward deviancy. If peers, family, school, and judicial system do not affect positively on individual, than they will engage in bad, unlawful activities and these activities are called as interpersonal interaction with above socializing agents.

\begin{abstract}
Syed Asad Ali Shah, 17 year old boy from Chungi Ammaratsar, district Lahore and he was charged for murder, gang firing, robbery, theft, \& illegal weapon under section324/ $34,13 / 20 / 65,401$. The respondent and his friend (co-worker at factory) planned to loot his neighbor (a doctor by profession) with two other friends. On occurrence day, the offender with his fellows went at the victim's clinic for robbery and tried to snatch the money at gunpoint. He resisted on attack and recognized the offender and other his fellows as they were the members of the same community and well familiar with each other. The victim started shouting for defence. The offender started firing at him unintentionally, and the victim died on the spot. They looted him and run away, leaving their motor bike at the occurrence place.
\end{abstract}

\title{
3.3 Poverty, illiteracy and inequality
}

The inequality and poverty are the major causes of criminality in any society. This is also reported with the strain theory of Robert K. Merton's, (1968) in which he stated that people of lower class face strain and anomic conditions, When they are unable to get the legitimate means by conventional goals. This excessive disparity between the culturally defined goals and legally approved mean, push the poor people to get the conventional goals by illegitimate means.

On the other hand Becker, (1968) also described the relationship between economic conditions and crime rate as usually unlawful acts comes from in the consequences of rationalization based on cost benefit analysis. He stated that a delinquent is not a helpless victim oppressed by society, but he could also be a rational economic person who commits a crime for his economic benefit.

As one respondent stated as;

"Poverty is a curse as my father sold his kidney for paying back the debt to the landowner. The landowners and powerful people commit crimes, and blamed their workers. They hired professional criminals or poor, helpless people for serious offenses, and they remain involved in all violent crimes but the law always accused only poor". Muhammad Ehsan

He further stated as;

"I could not attend school instead of my burning desire due to poor socioeconomic conditions of my family." Muhammad Ehan

Another respondent claimed as "My family suffered a lot as my maternal and parental relatives did not support us after my father's death. I discontinued my studies due to poor economic conditions of my family". Syed Asad Ali Shh

This shows that in conjunction with poverty, illiteracy is also a key factor behind delinquency. Chester, (1976) also concluded that poverty is also considered as an important factor toward criminality as he mentioned that crime and poverty has strong link with each other. The poor people have more chances to indulge in criminal act. They usually remained involved in street, property and nonviolent crimes. On the other hand, education is also linked with criminal tendencies as Hawkin et al, (1987) concluded that education can also play a vital role in conduct and personality development. It is perceived that low educational performance and low commitment with studies could become causes of the delinquency.

Muhammad Ehsan, a 14 year old boy lived in a slum area, 2 Chak Rakh Dhareema, District Sargodha was convicted of murder during robbery and use of illegal weapon. He could not attend school instead of his burning desire due to poor socioeconomic conditions of his family. Ehsan's father was over head and ear in debt. His mother was a heart patient and father sold his kidney for the sake of returning loan of 90,000 rupees to his land-owner. At the age of 10 year, he started working as daily wage labor in the construction of buildings and in the garden for plucking oranges. Briefly stated the story of the accused was that he belonged to a poor family and he wanted to attain all the things which he desired. On occurrence day, they took their pistols and went on the main road of 2 Chak. A person named Bilal, (30 year old, unknown to offend) was coming with his motorcycle. They connoted to the victim for help as they wanted to stop him for taking a lift, but the victim did not stop his motorbike, and offender shot the victim. The victim fell down due to an imbalance created by his leg injury. The offenders tried to snatch his money and motorcycle, but victim started resisting and started shouting for help. Unintentionally offender shot him again, and the victim died on the spot due to brain injury. 


\subsection{Exposure to Violence at Television}

Bandura, (1963) linked crime with the process of social learning by the performance of television characters and their performance helped in shaping the behaviors, outcomes, and nature particularly aggressive nature. According to this theory, it is described that aggression and violence come through the process of socialization and media is considered as an important socializing agent. One respondent claimed as;

"I usually spend most of the time in the front of the television, watching international dramas and movies. On the occurrence day, I watched an Indian movie "wanted" and wished to act like that. I took my pistol and went to the Ajnala road and committed this crime due to immaturity. There is no difference between fiction's characters and real characters, but the bad thing which happened to me is that police caught me". Nasir Ali

So, it is found that exposure to violence at television also leads toward delinquency.

\subsection{Psychological disorders}

There are many psychological disorders lead the children toward criminality. The report shows that the ratio of children having a psychiatric disorder is up to $17 \%$ in primary school, which is higher from than the world average arise due to lack of parental love (Hassan, 2010). This is usually caused by deprivation from parental love as love is the basic need of all the human beings. There are many psychological problems arise, such as depression, over hypersensitivity, intolerance, pretentiousness, and other chronic diseases among children as diabetes, obesity, heart attack etc.

As one respondent claimed as;

"I left school as I heard some (none existed) voices and saw the bodies wandering around me. I just wanted to get rid of it so that's why I started to take drugs as a reliever. I could not sleep well due to these voices and moving bodies around me during whole night". Asghar Khan

He wanted to get rid off from his psychological disorder so that's why he indulged himself in criminality (drug addiction and for fulfillments of this need he earn money by working as drug carrying).

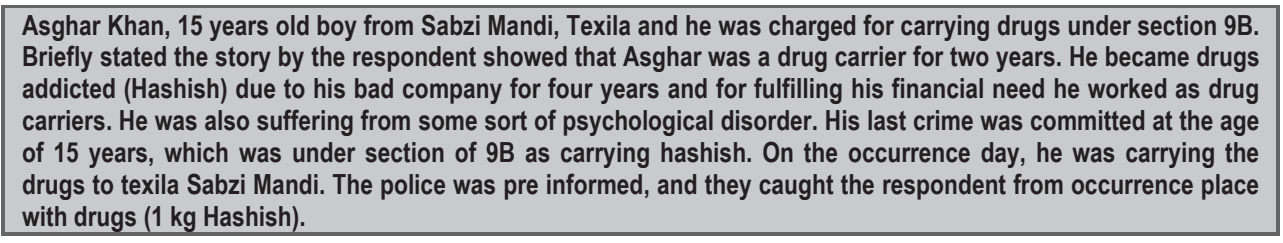

\subsection{Drugs and Deviancy}

There are the different ways by which drug leads toward criminality i.e. psychopharmacological effects (having low self control or irrationality), economic need (need for money to pay for drugs) and drug business etc. the psychopharmacological effects become the cause of aggression and violence, economic need become the cause of robberies and burglaries, and drug business also lead toward violent crimes (Conkin, 2003). If once, these juveniles commit crimes, they are stigmatized for their life time. The jail environment and society's response over their release from the jail push them again toward delinquency. They could not adjust in the conformist society with conventional means and goals. They are forced to join the delinquent gangs and deviant lifestyle once again. It is major need to rehabilitate them with good surroundings, teachings and trainings for their better future.

Moreover, some stories by the respondents show that drugs also become the cause delinquency. Some participants of my research were drugs addicted, drug carriers, and some has close exposure to drugs related crimes.

As one stated as;

"I became drug addicted at my early age due to the bad company of my peers and school administration expelled me from school due to my habit". Shahid Maseeh 


\section{Conclusion}

Juvenile delinquency is a global problem and impacting every segment of society from individual to the state level. The present study concluded that family is most significant factor behind juvenile delinquency. There are many sub-factors found in society i.e. the negative environment of families, parental negligence, single parent families, step parents, lack of proper supervision or authority by parents, too much strictness for discipline at homes, parental conflicts, exposure to violence, domestic violence, family motivation to commit crimes, low socioeconomic conditions of family, parental illiteracy or lack of moral education leads to delinquency among juveniles. On other hand the negative peer influence and delinquent communities or neighborhood also play key roles as negative socializing agents for immature persons. Moreover, the media, particularly television action programs, i.e. drama and especially action movies had become a major contributor for creating a negative influence on juveniles. It is also concluded that poverty, illiteracy, poor educational performance, delinquent neighborhood, and some sort of psychological disorders leads toward delinquency.

\section{Suggestions}

1. The family should have to become concerned about the future of their children. The education of the parents can be helpful in reducing the juvenile delinquency. The negative stigmatization at an early age should be discouraged.

2. Media should have to provide the awareness about juvenile behaviour, parental attitude, and defensive measures to tackle the problem at a very early age. The government should have to take some necessary steps for making useful policies about media transmission programs, the unnecessary or negative programs should be banned.

3. The policies and initiatives should be taken for the benefit of the country instead of personal motives.

4. As according to the rule, the arrested juvenile must be produced before the juvenile courts within 24 hours. The accused families should be informed very soon by the police for their children's imprisonment.

\section{References}

Anderson, C. A. (2000). AGGRESSION. Encyclopedia of Sociology. 2nd addition, 1

Bandura, A., Ross, D., and Ross, S. (1963). Imitation of film-mediated aggressive models. In Greer, C. (2010). (Ed.). Crime and media: $A$ reader. London: Routledge.

Becker, G.S. (1968), "Crime and Punishment: An Economic Approach", Journal of Political Economy, 76 (2): 169-217. Becker, (1968)

Breivik, Kyrre, Dan Olweus, and Inger Endersen. 2009. Does the Quality of Parent-Child Relationships Mediate the Increased Risk for Antisocial Behaviour and Substance Use Among Adolescents in Single-Mother and Single-Father Families?\|l Journal of Divorce \& Remarriage, 50:400-426.

Bor, W., Najman, J.M., Andersen, J., O'Callaghan, M., Williams, G.M., and Behrens, B.C. 1997. The relationship between low family income and psychological disturbance in young children: An Australian longitudinal study. Australian and New Zealand Journal of Psychiatry 31(5):664-675.

CANTER, R.J. (1982). Family Delinquency. Criminology, M. (1974). Hellfire and Journal of Scientific study of Correlates of Male and Female 20(2):149-167.

Chester, C. R. (1976). Perceived relative deprivation as a cause of property crime. Crime \& Delinquency. Retrieved April 26, 2007, from Sage Criminology database.

Coie, J.D., Miller-Johnson, S., Terry, R., Lochman, J.E., Maumary-Gremaud, A., and Hyman, C. 1995. The influence of deviant peer associations on juvenile offending among African-American adolescents. Paper presented at the annual meeting of the American Society of Criminology, Boston, MA.

Conklin, John E. 2003. Why Crime Rates Fell. Portland, OR: Book News, Inc.

Datesman, S.K. \& Scarpitti, F.R. (1975). Female Delinquency and Broken Homes. Criminology, 13:33-52.

Demuth, S., \& Brown, S. (2004). Family structure, family processes, and adolescent delinquency: The significance of parental absence versus parental gender. Journal of Research in Crime and Delinquency, 41(1), 58-81.

Elliott, D.S., and Menard, S. 1996. Delinquent friends and delinquent behaviour: Temporal and developmental patterns. In Delinquency and Crime: Current Theories, edited by J.D. Hawkins. New York, NY: Cambridge University Press, pp. 28-67.

Gumus, Erdal (2004), Crime in urban areas: An empirical investigation. Akdeniz I.I. B.F. Dergisi, Volume 7, pp. 98-109.

Hassan, S. 2010. Parent and teacher based epidemiological survey of psychiatric morbidity amongst school children in Karachi, Pakistan. PhD thesis. Department of Health Sciences, University of Leicester.

Hawkins, J.D., Lishner, D.M., Jenson, J.M., \& Catalano, R.F. 1987. Delinquents and drugs: What the evidence suggests about prevention and treatment programming. In Youth at High Risk for Substance Abuse (DHHS Publication No. ADM 87-1537), edited by B.S. Brown and A.R. Mills. Washington, DC: U.S. Government Printing Office, pp. 81-131. 
Jones, M.B., Offord, D.R., \& Abrams, N. (1980). Brothers, sisters and antisocial behaviour. British Journal of zsychiatry, 136, 139-145.

Lahey, B.B., Piacentini, J.C., McBurnett, K., Stone, P., Hartdagen, S., and Hynd, G. 1988. Psychopathology in the parents of children with conduct disorder and hyperactivity. Journal of the American Academy of Child and Adolescent Psychiatry 27(2):163-170.

Loeber, R., \&Stouthammer-Loeber, M. (1986). Family factors as correlates and predictors of juvenile conduct problems and delinquency. In M. Tonry and N. Morris (Eds.), Crime and justice, vol. 7. Chicago: University of Chicago Press.

McCord, J., Widom, C.S., and Crowell, N.A., eds. 2001. Juvenile Crime, Juvenile Justice. Panel on Juvenile Crime: Prevention, Treatment, and Control. Washington, DC: National Academy Press.

Postman, N. (1982). The disappearing child. In N. Postman, The disappearance of childhood (pp. 120-142). New York: Vintage.

Robert K. Merton, Social theory and social structure, enlarged. (New York: Free Press, 1968).

Shoemaker, Donald J. 2010. Theories of Delinquency. New York, NY: Oxford University Press.

Talpur, F., P. A. \& P. Shah (2011). Examining the causes of juvenile delinquency in Pakistan. Annual Research journal Vol. 4. 